\title{
REPORT ON THE NEUROPTEROID INSECTS OF THE HOT SPRINGS REGION, N.Z., IN RELATION TO THE PROBLEM OF TROUT FOOD.
}

\author{
By R. J. Tillyard, M.A., D.Sc., F.L.S., F.E.S., Linnean Macleay Fellow \\ of the Society in Zoology.
}

(With two Text-figures.)

On arrival at Auckland from Sydney on November 5th of last year, I was met by Mr. D. Miller, Government Entomologist, and Mr. H. Hamiltor, Zoologist to the Dominion Museum, and proceeded with them to Rotorua, where I met Mr. Moorhouse, in charge of the Fish Hatehery in Lake Rotorua, and Mr. Hill, Head of the Tourist Department. All these gentlemen offered me every assist. ance in carrying out my investigations, and I desire to thank them very sincerely for their aid.

Three weeks were spent in the Hot Springs Region, the following being the itinerary :-

Nov. 7th-10th: Rotorua. Visited Te Wairoa, Whakarewarewa and portions of the Lake.

Nov. 11th-17th: Te Wairoa and Lake Tarawera.

Nov. 18th-19th: Rotorua. Visited Fairy Spring, Hamurana Spring, Lake Rotoiti and Okere Rapids.

Nov. 20th-21st: Wairakei and Taupo.

Nov. 22nd-26th: Tokaanu.

Nov. 27th: $\quad$ Lake Roto-Aira.

Nov. 28th: Waimarino.

It was hoped that a return visit might have been arranged later in the season (February) in order to see the other lakes and streams of this region, and to study the insects in the height of summer. Circumstances, however, made it impossible to earry out this plan.

The work done in the field may be divided into two parts:-

(i.) Examinations of the contents of trout-stomachs.

(ii.) Collection of the larvae and imagines of Neuropteroid Insects from the streams and lakes.

\section{(i.) The Contents of Trout-Stomachs.}

An examination of a considerable number of trout-stomachs during the month of November showed a great diversity of food eaten. The Green ManukaBeetle, Pyronota festiva, was found to be the most abundant food. This beetle visits the Manuka bushes fringing the lakes and streams, and frequently falls or is blown off into the water, when it is at once seized and swallowed by the trout. Next in importance to this were found to be the larvae of the Caddis-flies of the family Leptoceridae, which form their eases of the green weed Nitella. The stomachs of a number of trout were found to be filled with this green weed, which, on being placed in a basin of water was seen to consist entirely of caddis-fly 
eases, many of the larvae being still alive within the trout's stomach. Another important food was a small Molluse, Potamopyrgus sp., of which no less than 140 were counted in the stomach of a "slab" taken at Rotorua. Other foods found less commonly were the larvae of Dragonflies, Mayflies, Stoneflies and the other families of Caddis-flies, occasional remains of the Crayfish, small fish, and a number of insects of various kinds which may be considered to have no definite value as trout-food being only chance captures.

Besides these, it is important to note that some trout-stomachs were found containing nothing but pebbles, and several were quite empty.

A considerable number of the trout examined were definitely "slabs." The slabby condition appeared to be due, not only to the usual poor health of the fish for some months after spawning had taken place, but more definitely to both semi-starvation and indigestion. It was not surprising to find that fish with their stomachs empty, or only filled with pebbles were in poor condition. But there were also cases in which the slabby condition appeared to have been caused by the indigestibility of the food. In one case the large claws of a crayfish were found fixed inside the stomach of a trout in such a way as to block the passage of other food; and they had evidently been there a considerable time, seeing that all the rest of the animal had been completely digested. This led me to conclude that the crayfish is only a good food for trout when it is of not too large a size. Consequently the introduction of any larger or more vigorous species of erayfish than the one endemic in the region ought not to be encouraged.

\section{(ii.) The Neuropteroid Fauna of the Streams and Lakes.}

The Neuropteroid Insects inhabiting the streams and lakes of the Hot Springs Region may be divided into six Orders, three of which belong to the more primitive division of the winged insects, viz., those that have no true pupal or resting stage (Hemimetabola) and three belong to the more highly evolved division, possessing a true pupal stage (Holometabola). They may be classified as follows:Division Hemimetabola: (Winged insects without a true pupal or resting stage).

Order 1. Perlaria or Stone-flies.

,2. Plectoptera or May-flies.

, 3. Odonata or Dragonflies.

Division Holometabola: (Winged insects possessing a true pupal stage).

Order 4. Megaloptera or Alder-flies.

, 5. Planipennia or Lacewings.

„6. Trichoptera or Caddis-flies.

(Note-The Scorpion-flies, Order Mecoptera, are not represented in the Region under discussion.)

Of the six Orders enumerated we may omit from the discussion Order 5 (Lacewings) whose larvae are either terrestrial, or else lurkers along the moist borders of streams. They attack the larvae of the other Orders which are of value as food for trout. Thus, in so far as they affect the problem at all, they act detrimentally to the food-supply. But they are exceedingly rare in the Hot Springs Region, and were only found by me in two localities, viz.: Hamurana Spring, and the waterfall at Wahi, near Tokaanu.

Order 4 (Alder-flies) is only represented in New Zealand by a single species, Archichauliodes dubitatus, an insect of large size, whose fat, suceulent larva is found under rocks in streams, and forms an excellent food for trout. This larva is called the "Black Creeper," or sometimes the "Toe-biter." Though very abun- 
dant in most parts of New Zealand, it appears to have been exterminated by the trout in most parts of the Hot Springs Region, though it is still fairly abundant on the Tongariro River and tributaries.

The other four Orders, Stone-flies, May-flies, Dragon-flies and Caddis flies, are of the greatest importance as trout-food, and we have to consider them in somewhat greater detail.

\section{The Stone-flies.}

These insects confine themselves to running water, preferring rocky streams, with a fairly fast current. Their larvae live on rocks and stones, where they wander freely in search of food. The perfect insects, or imagines, are sluggish, and seldom fly, preferring to sit about on the vegetation overhanging the streams. Nevertheless, they frequently fall into the water, and are eagerly seized by the trout. Both larvae and imagines are soft-bodied insects with a plentiful supply of fat, and form an ideal and easily digested food for trout.

Except along the Tongariro River and its tributaries, where the Stone-fly fauna is still abundant, these insects are very rare in the Hot Springs Region; and it is very elear that they have been greatly reduced in number by the trout.

The large green Stone-fly, Stenoperla prasina, generally abundant throughout New Zealand, and one of the best of trout-foods, was only to be found in streams above high waterfalls, where trout were absent. It has been almost completely annihilated in the Hot Springs Region.

The Black Stone-fly, Austroperla cyrene, the most abundant Stone-fly throughout New Zealand, has likewise been almost eliminated by the trout. A colony of larvae was discovered at the extreme head of one of the small streams at Hamurana. There are also a few larvae left here and there in the Tongariro River.

Of the slender Stone-flies (family Leptoperlidae) a number were found on the Tongariro River and its tributaries. Some of these are new to science, and will be described later. But, generally speaking, it may be said that these valuable flies, like the rest of the Perlaria, are on the verge of extinction in the Hot Springs Region.

It would, I think, be well within the mark to estimate that more than $80 \%$ of the original Stone-fly fauna of the Region has already been destroyed by the trout.

$$
\text { The May-flies. }
$$

These insects inhabit both streams and lakes. In all parts of the world they form one of the most important articles of diet for the trout. Both the larvae and the imagines are soft-bodied and easily digested. In the Northern Hemisphere, where the evolution of the May-flies has taken place alongside that of the native trout, the larvae have resorted to many eunning devices in order to escape their rapacious enemies. Those of the larger species mostly burrow into the banks of streams, and thus secure immunity from attack; while the smaller forms hide under rocks and stones, and evade attack by their quick running powers. Thus the trout only secure the May-flies in their winged stages (subimago and imago).

In New Zealand, the native May-fly fauna has been evolved without exposure to the attacks of rapacious fish such as the trout. There is only one large species whose larva burrows into the river-banks, viz., Ichthybotus hudsoni; and it is elear, for many reasons, that this May-fly did not evolve this habit in New Zealand, but migrated thither long after the adoption of it. All the rest of the 
large May-flies, forming together a magnificent fauna unequalled in any other part of the world, have evolved little or no protective habits against such a fish as the trout. The larvae of Oniscigaster, one of the finest May-flies in the world, sit about on rocks or on the gravelly bottoms of streams; and, when attacked, they only wriggle forward like a shrimp. Consequently they have become an easy prey to the introduced trout, which gorged themselves for some years on this large supply of choice food. This magnificent genus is now quite extinet throughout the Hot Springs Region, and also in the streams around Christehurch, though still to be found here and there in out-of-the-way places in both Islands. Another fine genus, Ameletus, has larvae capable of quicker movement, and is therefore still fairly abundant in most parts of New Zealand. But these larvae are also on the verge of extinction in the Hot Springs Region. I did not discover a single Ameletus larva throughout my investigations, though I caught a fine imago of a new species belonging to this genus above the high waterfall at Wahi, near Tokaanu, where trout are absent. A third May-fly genus of great importance is Coloburiscus. The larvae have a certain amount of protection against the trout, owing to their bizarre form, their gills being arranged so that they look like a small piece of tangled moss or weed. They are very sluggish and hide under rocks and stones in running water. Coloburiscus humeralis is one of the most abundant May-flies in New Zealand; yet it has been practically eliminated from all parts of the Hot Springs Region, except only on the Tongariro River and its tributaries, and on those small streams where trout are absent, from some cause or other, such as the intervention of a high waterfall, as at Wahi.

Besides the larger May-flies mentioned above, there are two genera of smaller May-flies, Atalophlebia and Deleatidium, containing numerous species which are very abundant all over New Zealand. The larvae live under rocks and stones in streams and lakes, and are fairly active. Most of them are vegetable feeciers, but a few are carnivorous. A number of species of these genera were collected, some of them new to science. These latter will be described later. Throughout the Hot Springs Region, a very considerable diminution of the supply of the small May-flies is noticeable; and this cannot fail to exercise a serious effect upon the future of the trout.

To sum up the position, we may say that the largest May-flies, which form the very finest possible food for trout, have been practically exterminated, while the smaller forms have been reduced, at a moderate estimate, by over $50 \%$.

\section{The Dragon-flies.}

New Zealand is poor in species of Dragonflies, but most of them are common. Seven species are found very commonly throughout the Hot Springs Region. Of these the largest (Uropetala carovei) is of no importance as trout food, the larva dwelling in holes in the moss and peat of swamps. The larvae of the bright red Diplacodes bipunctata, dwelling in still back-waters, may also be left out of account. The larvae of the other five were all found by me in the stomachs of trout, the most frequently oceurring being those of Procordulia smithii, Pr. grayi and Xanthocnemis zelandica. No doubt, later on in the season, the trout would also feed upon the imagines, as in Tasmania.

In certain parts of New Zealand, I found Dragonfly larvae to be the principal food of the trout. In the Hot Springs Region, the trout seem to have considerably diminished the number of larvae, and they do not form so important an article of diet, perhaps because they are more protected by their peculiar colour- 
ation and habits than are some other aquatic insect larvae, such as those of Mayflies. It seems clear that their numbers have been much decreased since the trout were freed in these lakes and rivers, although I am unable to estimate this reduetion as clearly as in the eases of Stone-flies and May-flies.

$$
\text { The Caddis-flies. }
$$

Observations in other parts of the world, as well as in other parts of New Zealand, show that Caddis-fly larvae form one of the most important articles of diet for the trout. Most of these larvae construct eases for themselves out of weeds, sticks, sand or small pebbles; and one would imagine that such habits as these would serve as efficient protection for them. But this is not the ease. The trout know well the habits of the Caddis larvae. They watch earefully for any suspicious movement amongst the weeds, sticks, etc., that strew the bottoms of the lakes and streams, and they pounce upon the larvae and swallow them whole in their cases. The substance of the case is usually indigestible; but the larva itself is a succulent, fat morsel, and an excellent food for the fish. Those most sought after are the elongated, more or less cylindrical cases of the Leptoceridae and Sericostomatidae, the former usually made from weeds, pieces of leaves or sticks, the latter from grains of sand or a thin transparent substance secreted by the larva itself. In the Leptoceridae, the genera Notanatolica, Triplectides and Oecetis are abundant throughout New Zealand; in the Sericostomatidae the same is true of Olinga and Pycnocentria. Throughout the Hot Springs Region the trout have most seriously diminished the number of these and other Caddis-flies. Only two species now remain at all common, viz., Oecetis unicolor, whose larva is still common, feeding in the green Nitella-beds in the lakes, and Hydropsyche colonica, whose larvae form fixed houses of small pebbles attached to rocks. This iatter species still exists in great numbers in such places as the Okere Rapids, where the rush of water is too swift for the trout to search for it. Its comparative absence in other parts is strong evidence of the reduction of the Caddis-fauna, due to the trout.

The most striking instance of the almost complete loss of the original rich Caddis-fauna is afforded by the condition of the Te Wairoa stream, flowing into Lake Tarawera. Except in the rough water below the Falls, where no trout exist, it is almost impossible to obtain any eaddises in the stream. But a short distance off there is a much smaller stream, rising from a hill near the lake. This stream has been dammed off by boards, and the water drawn off close to its exit into the lake by a force-pump. No trout pass up this small stream. On examining it I found that it was swarming with eaddislarvae under every stone and stick, and upon the gravelly bed and sides of the stream these little ereatures were most abundant. Yet a day's search in the Te Wairoa stream yielded far less than I was able to pick out in the course of ten minutes in this tiny stream a mile away from it.

It would not be overestimating the depredation eaused by the trout amongst the Caddis-fauna of the Hot Springs Region, if the loss were put at $90 \%$ of the original fauna.

\section{The State of the Insect Food Supply.}

My survey of the insects of the Hot Springs Region quickly convinced me that the balance of nature has been completely upset by the introduction of the trout. By comparison with the state of affairs in most parts of the South Island, 
where the fauna, though seriously reduced in many places, is usually found to be more abundant than it is in this Region, it appears certain that the Rainbow Trout has had a greater share in the eating-out of the insect fauna than has the slower and less greedy Brown Trout. The history of the Trout-fisheries of the Region may be briefly stated as follows:-

(i.) Before the introduction of the trout the rivers of New Zealand swarmed with an aquatic insect fauna as abundant as that to be found in any part of the world. The lakes carried a less abundant fauna of fewer species.

(ii.) The great majority of these insects, having evolved to their present state without the stimulus of the predatory action of any rapacious fish, possessed no means of defence against the trout when they were introduced.

(iii.) The introduced trout, and especially the Rainbow, gorged themselves at leisure upon the rich food; so that, in the course of a few years, trout of record size were being eaught, and the fisheries obtained a worldwide reputation.

(iv.) No scientific attempts have been made to conserve or renew the foodsupply. On the contrary, the only idea seemed to be to put in more and more fry.

(v) As soon as the food supply began to fail, some of the trout became weakened; "slabbiness" became noticeable; and disease in the form of thread-worm and fungoid growths appeared. There is also considerable evidence of actual starvation of trout in certain streams.

(vi.) Some attempts have been made of late years to reduce the number of trout by netting and trawling. These efforts may be said to have brought about some slight improvement in the condition of the fish. At the same time, the destruction of shags has diminished the prevalence of the thread-worm (of which the shag is said to be the intermediate host). But the disease is by no means stamped out, and most certainly requires further careful study.

The present position of the trout-fisheries of the Hot Springs Region is that there is, throughout most of the Region, not enough food for the trout present. Many of the streams, especially those in which the fish spawn regularly, are almost totally "eaten-out," and the amount of food in the lakes is woefully deficient. The only part of the Region in which the state of affairs ean be deseribed as at all hopeful, so far as my investigations go, is the Tongariro River and its tributaries, where the supply of food is still fairly abundant.

One might sum up the position, somewhat caustically, by comparing it with that of a grazier who put 10,000 head of cattle into a very rich 1000 -acre paddock, left the animals to feed, and, when the food supply began to fail, prepared to remedy it by putting in a fresh supply of ealves every year, without making any attempt to improve the impoverished food supply!

\section{(iii.) Recommendations.}

It is clear that improvement in the Trout fisheries of the Hot Springs Region ean be effected along two distinct lines, viz. :-improvement of the food supply and reduction in the number of trout. No considerations of the attractions to tourists or anglers, from a super-abundant supply of trout, should be allowed to cloud the main issue, which is this, that, unless a natural balance can be brought about 
between the introduced trout and the food supply, the fisheries are sooner or later doomed to failure.

With regard to the improvement of the food supply, the position is at present a very serious one, in so far that the balance has been so greatly upset, that no measures for the introduction of fresh types of food ean be expected to succeed, unless such food is most earefully protected until it becomes well established. It is, therefore, necessary to adopt at once measures which will not only heip to conserve the remnant of the food supply still existing, but will also give the aquatic fauna a chance of multiplying and approximating towards its original abundance. To bring this about I would make the following recommendations:-

1. A badly impoverished stream should be selected, and should be completely blocked by means of specially designed trap-nets, so as to prevent any trout passing up it to spawn; also any trout at present in it should be taken out. Aquatic insects should then be introduced from neighbouring small streams where no trout exist (e.g., such parts of streams as lie above high waterfalls), and a sareful record kept by means of annual or biennial visits, upon the progress of the aquatic insect life in the stream. I estimate that it will take at least three years, possibly five, for such an impoverished stream to return to its original condition. If, at the end of two or three years, it becomes evident that the aquatic fauna is increasing, steps should then be taken to block off in the same way each spawning stream in turn; so that, in any given year, there will only be certain streams open to the trout for spawning, while the rest will be given a chance of recuperation.

For this purpose I would recommend either of the following two streams:-

(a) The Te Wairoa stream, from the waterful to the outlet of Lake Tarawera. (There is an abundant supply of aquatic insects in the small ereek on the lefthand side of the road leading down to the wharf, about a mile from the Te Wairoa stream).

(b) The Tokaanu stream. (Aquatic insects are abundant in the small streams around Wahi, two miles away.)

In both cases, the nature of the river-bed (pumice) and frequency of flood water make it impossible to block the stream by means of stake or pile-nets. I would, therefore, recommend that the nets be strung on strong supports driven into the banks, and that their lower ends should hang freely into the stream, and earry lead weights at short intervals. The accompanying diagrams (p. 212), show the type of net to be used.

If at the end of three years there is no sign of the native aquatic insect fauna reasserting itself, I would recommend that an attempt be made to introduce the English "Creen Drake" Mayfly, Ephemera danica, or such other species as are known to be of great value as food for trout. These could be set free in the larval condition in the streams selected as a sanctuary under recommendation (2) following this below.

2. It is of the greatest importance that one lake, together with the streams flowing into it, should be set aside as a sanetuary for the natural food-supply. Most unfortunately, this aspect of the question was not considered when the stocking of the streams with trout was undertaken. The result is that there is at present no lake in the Rotorua District which does not contain trout. In the Taupo District, an undertaking was given by the Government to the Maoris that Lake Roto-Aira should be kept free from trout. Unfortunately, trout were surreptitiously introduced into this lake two years or more ago, and have grown to a 

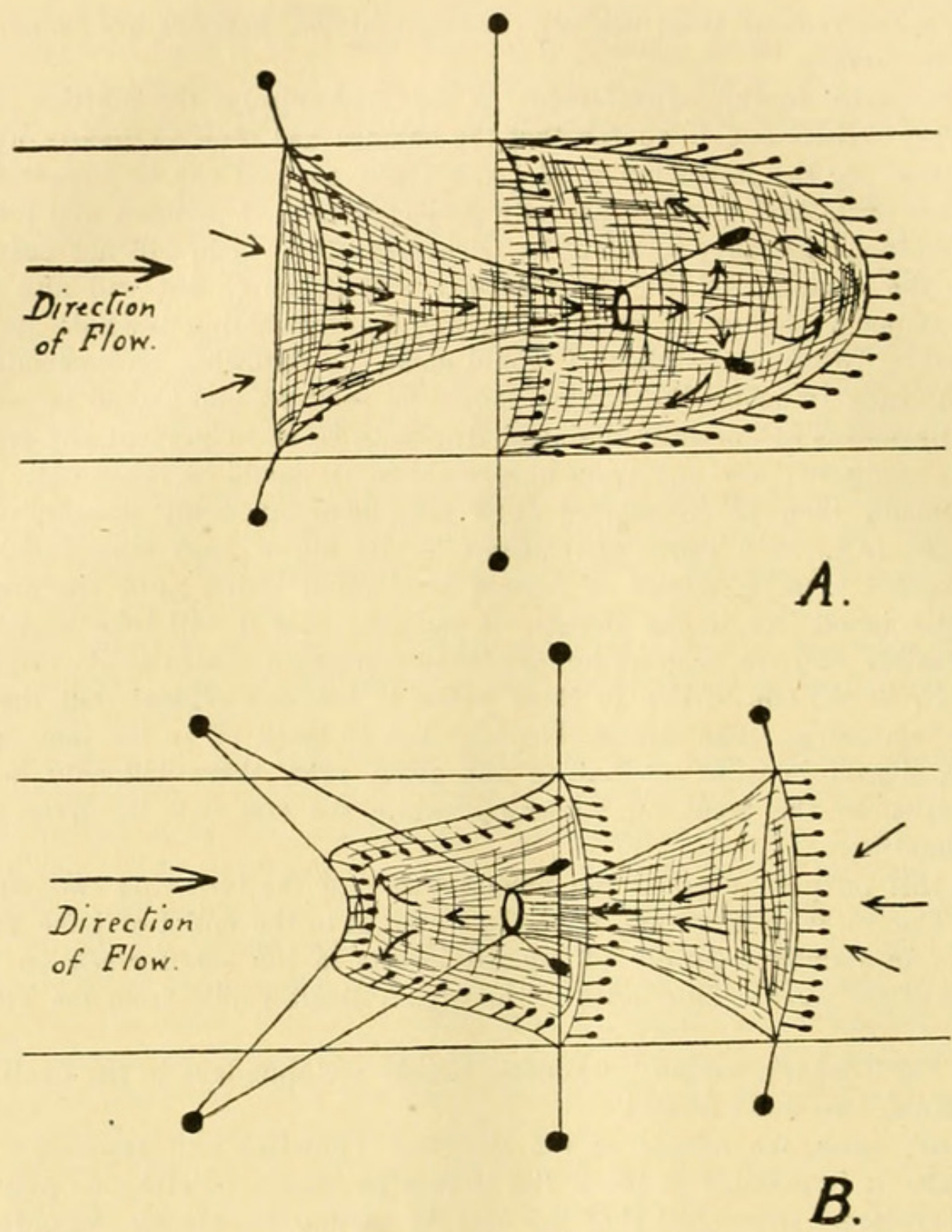

A. Double trap-net with leaded bottoms, suitable for river with unstable pumice bed, and set so as to eatch trout running downstream.

$B$. The same net, set with two extra pairs of steel-rope braces, so as to catch trout running upstream.

The arrows indicate the courses taken by the trout.

$N . B$. - The nets should be so designed that plenty of "slack" is allowed for above the leaden weights, so that, if a flood washes the pumice bottom out, the slack will allow the net to sink without lifting the weights from the bottom.

considerable size. Roto-Aira is at present the only possible lake that could be maintained as a sanctuary.

I would therefore recommend that this Lake, together with all streams Howing into it, and the Pouto River flowing out of it, to within a mile of its entry into the Tongariro River (or to such point as will be suitable for the erection of nets to prevent access of trout) should be proclaimed as a sanctuary for the native aquatic fauna, and that immediate steps should be taken to eliminate from this area any of the trout that were surreptitiously introduced. 
3. Following upon (2), steps should be taken to have an exhaustive scientific survey made of the natural trout-food existing within the bounds of the sanctuary, and experiments made with a view to improving it. I think this could be done by erecting a small Biological Station in a convenient locality near the sanctuary lake, and either placing it under the charge of a competent biologist, or else affording facilities for leading scientists to visit the station and study the fauna. In this connection I should like to point to the Cass Biological Station, which is under the charge of Prof. C. Chilton, and is owned by Canterbury College, as an excellent example of what can be accomplished in this direction at a very moderate cost.

With respect to methods for reducing the number of trout, I would point out, in particular, that over-sized fish are a serious menace to the success of a troutfishery, because they not only consume far more food than do their equivalent weights of smaller fish, but they also take possession of the best feeding grounds, prevent the younger fish from obtaining an adequate food supply, and frequently themselves make inroads upon the smaller trout. With the maximum possible native food-supply, a New Zealand fishery ought not to be expected to produce anything beyond a steady and assured supply of reasonable-sized fish; and it should be one of the chief aims of a scientific directorate to produce this very desirable result. Consequently means must be devised, not only for reducing the general very obvious conditions of overstocking in the lakes which I visited, but also for removing "pirates" and over-sized fish wherever possible.

4. A more vigorous policy of netting the trout, either by the use of trawlers or small launches, on Lakes Taupo, Rotorua, and Tarawera. The money realised by the sale of such trout, either fresh or smoked, should be devoted to objects which might further the scientific study and direction of the fisheries; as, for instance, the provision of a Biological Station advocated under Recommendation (3).

5 . The adoption of the regulations generally in use in the South Island concerning permissible baits; i.e., besides the artificial fly, it should be allowable to take trout on the natural fly, grasshopper, etc. I am well aware that all true sportsmen abhor anything but the artificial bait; but it is time that they realised that every inducement must now be offered to get a marked reduction from the present seriously over-stocked condition of the lakes.

6. Limitation of spawning to certain selected streams, which should be changed from year to year when practicable. This has already been dealt with in connection with Recommendation (1).

The above recommendations, if adopted, may be expected to show good results, in the case of the Taupo fisheries, within a few years' time. The fisheries of Lakes Rotorua and Tarawera are a more formidable problem; and it would be advisable to attempt the solution, in these cases, only in the light of the experience gained from the treatment of the Taupo fisheries. 


\section{$2 \mathrm{BHL}$ Biodiversity Heritage Library}

Tillyard, R. J. 1920. "Report on the neuropteroid insects of the hot springs region, N.Z., in relation to the problem of trout food." Proceedings of the Linnean Society of New South Wales 45, 205-213. https://doi.org/10.5962/bhl.part.19540.

View This Item Online: https://www.biodiversitylibrary.org/item/24141

DOI: https://doi.org/10.5962/bhl.part.19540

Permalink: https://www.biodiversitylibrary.org/partpdf/19540

\section{Holding Institution}

MBLWHOI Library

\section{Sponsored by}

MBLWHOI Library

\section{Copyright \& Reuse}

Copyright Status: NOT_IN_COPYRIGHT

This document was created from content at the Biodiversity Heritage Library, the world's largest open access digital library for biodiversity literature and archives. Visit BHL at https://www.biodiversitylibrary.org. 